DOI:

\title{
MONITORING PROFESSIONAL COMPETENCE OF A LECTURER IN FOREIGN CITIZENS` LANGUAGE TRAINING
}

\author{
Olena Bielikova \\ Senior Lecturer \\ Kharkiv national university of civil engineering and architecture \\ (Kharkiv, Ukraine ) \\ e-mail: khnuba.ukrmova@gmail.com \\ belikova.lenochka@gmail.com \\ Svitlana Dytiuk \\ Senior Lecturer \\ Kharkiv national university of civil engineering and architecture \\ (Kharkiv, Ukraine) \\ e-mail: khnuba.ukrmova@gmail.com \\ Svetlanadytiuk@gmail.com
}

\begin{abstract}
The article analyzes the concept of "monitoring of the professional competencies of the lecturer of language training for foreign citizens", defines the role and place of diagnosis in the system of professional monitoring, highlights lecturer`s competence in teaching foreign students of technical specialties. The competence approach connected with the search of new conceptual and methodological models for training specialists with higher technical education, quality of training professional personnel, the definition of key competencies that a modern lecturer should have. The concept of competence and role of Russian (Ukrainian) language as foreign in the development of communicative competence of foreign students of technical specialties investigated. Strengthening the attention to the issues of diagnosing the level of proficiency of language training lecturers of professional competences, as a modern trend requires not only scientifically based tools for continuous measurement, analysis and improvement of evaluation of educational results of students' professional training, but also a new look at the system of pedagogical diagnostics. System diagnostics based on a competent approach should become a key and crosscutting component of monitoring the quality of vocational training of language training specialists in universities of technical profile.
\end{abstract}

Keywords: lecturer`s professional competence, language training, foreign students, universities of technical profile, competence approach, professional graphic monitoring

\section{МОНИТОРИНГ ПРОФЕССИОНАЛЬНОЙ КОМПЕТЕНЦИИ ПРЕПОДАВАТЕЛЯ ЯЗЫКОВОЙ ПОДГОТОВКИ ИНОСТРАННЫХ ГРАЖДАН}

\author{
Елена Беликова \\ Старший преподаватель \\ Харьковский национальный университет строительства и архитектуры \\ (Харьков, Украина) \\ e-mail: khnuba.ukrmova@gmail.com \\ belikova.lenochka@gmail.com \\ Светлана Дытюк \\ Старший преподаватель \\ Харьковский национальный университет строительства и архитектуры \\ (Харьков, Украина) \\ e-mail: khnuba.ukrmova@gmail.com \\ Svetlanadytiuk@gmail.com
}

\begin{abstract}
Аннотация. В статье осуществлен анализ понятия «мониторинг профессиональных компетенций преподавателя языковой подготовки иностранных граждан», определена роль и место диагностики в системе профессиографического мониторинга, выделены компетенции преподавателя по обучению языку иностранных студентов технических специальностей. Компетентностный подход связан с поиском новых концептуально-методологических моделей подготовки специалистов с высшим техническим образованием, качеством подготовки профессиональных кадров, определением ключевых компетенций, которыми должен владеть современный преподаватель.
\end{abstract}

Ключевые слова: качества преподавателя языковой подготовки иностранных граждан, компетентностный подход, педагогическая диагностика, профессиографический мониторинг, профессиональная компетенция 
INTRODUCTION. In conditions of social and economic changes in Ukraine, improving quality of a professional higher education system, in process of introduction of new requirements and standards of teaching, significant transformations of lecturer and student's interaction take place. Changes, first of all, concern to lecturer's perception, a system of role expectation as to lecturer's main qualities changes. That's why one of the most important questions in nowadays pedagogical discussions is a question about lecturer`s identity, his professional activity, about demands that are being made to him.

Objective of an article is research and justification of theoretical basements of diagnostics of results of forming professional competencies of language training pedagogues in universities.

Taking into attention special moments in foreign students' language training, it can be said that lecturer who trains foreign students:

- must have skills not only in language training, but also be familiar with culture of the countries that his students came from;

- $\quad$ must be native to language and culture of the country;

- must also know everything about culture of his students countries and highlight differences between cultures to his students;

- must master the culture of the language (his speech should be clean, diverse, different in words), stick to language etiquette.

LITERATURE REVIEW. Analysis of the latest researches and publications says that this problem is very promising. Actual problem of pedagogue's professional skills been researched by the following scientists: I. Zymnia, I. Zyazun, I. Podlasyy, V. Slastenin, E. Klimov, M. Kharlamov and others. Main ideas that unite different points of view of mentioned researches are the following - university lecturer is a person who, because of his professional activity, should have such professional qualities as: be a scientist, a practicing pedagogue, a mentor, a psychologist, master the technology of education process and procure the unity of educational, scientifical and innovational activities (Zimnyaya 2010; Podlasiy 2015; Slastenin 2015) Psychologist V. Krutetskyy suggests the following structure of modern lecturer`s personality: world view, positive attitude to pedagogical activity, pedagogical abilities, professional pedagogical knowledge, skills. T. Rudneva adds cognitive component and practical skills to modern lecturer's professional competence. (Rudneva p.56). T. Tkachova highlights personal qualities of a pedagogue as main, as ones that affect students` education level. "Pedagogue`s influence consists of his professional qualities, as a person who is master in his subject, and influence of his person, spirituality, emotionality. At the same time, personal skills are much more important than professional skills for students. When students appreciate their lecturer, it guarantees their love to him and his subject" (Tkachova 2015: 77).

Aggregate of professional demands to lecturer is specified as his professional willingness for his pedagogical activity. Inside it will be right to highlight, at one side, psychological and physical readiness, and at the other side - scientifical and practical competence as a basement for professionalism. System of professional demands to pedagogue consists of his professional competence. Till nowadays there is a lot of experience in building lecturer's professional competence, and it allows to split professional demands on three main groups, that are connected and complement each other: general citizen qualities; qualities that specify lecturer`s profession; special experiences and skills.

After analyzing psychological and pedagogical literature about the definitions mentioned above, we came up to a decision that the following competencies of a lecturer of foreign citizens' language training can be highlighted (Andreeva 2014; Kichuk 2007; Ortínskíy 2017; Ovcharuk 2004; Panina 2017; Slastenin 2015; Zimnyaya 2010):

1. General humanitarian competence. Problems of intercultural communication may be solved only under conditions of sufficient level of general humanitarian competence.

2. Linguistic competence. Knowledge of all key moments of the language he teaches is a main competence for language pedagogue.

3. Psychological competence. Teaching language will be successful if lecturer will take into attention personal qualities of his students, psychology of pedagogical activity and communication.

4. Pedagogical competence. Knowing base pedagogical conceptions, principles, categories and definitions, general knowledge about teaching methods lets lecturer optimize teaching process.

5. Methodical competence. Basement of this competence is in knowing theories, conceptions, methodical systems in teaching foreign students; in mastering skills and ways that allow teaching foreign students language.

6. Professional communicative competence. Ability to set optimal pedagogical connection with all participants of language teaching process, as a condition of lecturer`s professional competence.

RESEARCH METHODS. For analyzing special features of language training lecturer's perception that are important for students of our university we conducted a survey: "A lecturer in foreign students' eyes". Students of faculty of construction and faculty of architecture of Kharkiv national university of civil engineering and architecture took part in it. We set some definite tasks for studying personality of a modern lecturer, namely to determine:

1. Foreign students` general image about requirements to university pedagogue;

2. The most important for foreign students characteristics in lecturer`s professiogram;

3. Dynamics of university lecturer's image in the eyes of foreign students of different years of study.

This survey been held in several stages. On stage one foreign students of $3^{\text {rd }}, 4^{\text {th }}$ and $5^{\text {th }}$ year of study had to finish the sentence: "Modern university lecturer should be ..." by using their own thoughts. After processing the results of our survey, we made a list of lecturer's features that are important for students. Students of $1^{\text {st }}$ and $2^{\text {nd }}$ years of study had to 
rank the features from the list we got. Analysis of survey results showed the existence of two main groups: professional skills and personal qualities of a pedagogue.

RRESULTS AND DISCUSSIONS. According to results of our survey, foreign students consider that lecturer should have the following qualities and skills: professionalism ("easily explain", "explain difficult moments", "answer the questions"), rhetorical mastery ("teach in an interesting way", "speak in easy manner", "speak legibly"), communicability ("be communicable", "communicate respectfully", "be open to student", "be a friend for student"), wide area of thought ("open minded", "smart", "knows much"), mastery in subject ("be a master in subject", "deep knowledge"), kindness ("kind", "in good relations with students", "help a student"), self-control ("do not cry at students", " do not tease at students", "be calm"), internationalism ("don't be racist", "keep in mind that all students are equal: Ukrainian and foreign"), tolerance ("show respect to foreign culture", "show respect to foreign religion"), appearance ("good-looking", "neat"), empathy ("help the students"), strict, objective, honorable to students.

The most important skills appeared to be: "don't be a racist" - 60\%, "easily explain" - 55\%, "be a master in subject" $40 \%$, "smart" - 38\%, "be calm" - 33\%, "in good relations with students" - 30\%, "be communicable" - 30\%, "honorable to students" $-27 \%$.

During comparing characteristics given by students of younger and elder grades, we found out the following regularities.

Students of younger grades value lecturer's attitude more than his professional skills, master level, knowledge base: for younger grade student it is more important how lecturer communicates them, how kind he is, his tact. In evaluation of modern pedagogue image they value his personal qualities more. At $1^{\text {st }}$ place students of first and second grades put such quality as "being honorable to students", on $2^{\text {nd }}$ place - "internationalism", on $3^{\text {rd }}$ place - "kindness" and "communicability", on $4^{\text {th }}$ - "easily explain", on $5^{\text {th }}$ - "help a student".

Students of third, fourth and fifth grades value personal qualities of a lecturer and his professional skills at same degree. They highlight the qualities that relate to professional and personal qualities of a lecturer: "be a master in subject" and "easily explain" ( $1^{\text {st }}$ place); "honorable to students" and "kindness" ( $2^{\text {nd }}$ place); "self-control" ( $3{ }^{\text {rd }}$ place $)$; "objective" and "communicability" ( $4^{\text {th }}$ place); "appearance" ( $5^{\text {th }}$ place $)$; internationalism ( $6^{\text {th }}$ place $)$.

After analyzing the data above, the following conclusions can be made:

- In their lecturer foreign students should see a patriot of Ukraine. At the same time it is totally unacceptable for him to be a nationalist, to dishonor other countries or nations;

- An image of a lecturer consists of many factors of perception by students and contains several groups of qualities: personal qualities, that characterize lecturer as a personality; professional skills, that characterize his professional activity; social skills, that characterize his communicative skills, interaction with students;

- During teaching process lecturer's image in the eyes of the students changes;

- Effectiveness and optimization of teaching process in language training depends both on pedagogical mastership knowledge and skills in linguistics, pedagogics and psychology, and on personal qualities of lecturer's person.

CONCLUSION. Thereby, increased attention to questions of diagnosing language training lecturers` professional levels demands not only scientific look and analysis, but also a new look on systems of pedagogical diagnostics. System diagnostics based on competence approach must become a key and pass-through component in monitoring professional competence of a lecturer in foreign citizens' language training in technical universities.

Perspectives for continuing studies. An object for continuing studies is a study of an essence and structure of components for diagnosing professional competencies; definition of variable and invariable components of foreign students language training pedagogue`s professional competencies; justification of model and methods of system diagnostics of professional competencies.

\section{REFERECES}

Andreeva, G. M. (2014). Socialnaja psihologija: uchebnik dlja vuzov [Social psychology: textbook]. $5^{\text {th }}$ ed. Moscow: Aspekt Press. Bakhtin, M. M. (1986). Problema teksta v lingvistike, filologii i drugikh gumanitarnykh naukakh [Problem of text in linguistics, philology and other human sciences] in Bakhtin M. M. Aesthetics of verbal creativity. Moscow, pp. 297-325.

Karaulov, Yu. N. (1987). Russkij yazyk i yazykovaja lichnost [Russian language and language personality]. Moscow: Science.

Kichuk, N. V., (ed.) (2007). Kompetentnost samorazvitija specialista: pedagogicheskie osnovy formirovanija v vysshej shkole [Competence of the specialist's self-development: the pedagogical foundations of the formation in higher education]. Izmail: IGGU. Ortínskíy, V. L. (2017). Pedagogíka vishchoï shkoli: navch. posíb. [High school pedagogy: the textbook]. Kyiv: Center for Literature Studies.

Ovcharuk, O. V., (ed.) (2004). Kompetentnostnyj podhod v sovremennom obrazovanii: mirovoj opyt $i$ ukrainskie perspektivy: Biblioteka po obrazovatel'noj politike [Competence approach in modern education: international experience and Ukrainian perspectives: Library for educational policy]. Moscow: K.I.S.

Panina, S. V., Makarenko T. A. (2017). Samoopredeleniye i professionalnaya oriyentatsiya uchashchikhsya: uchebnik i praktikum dlya akademicheskogo bakalavriata [Self-determination and professional orientation of students: textbook and workshop for academic undergraduate]. ${ }^{\text {rd }}$ ed. Moscow: Yurayt, 2017, pp. 411-421.

Podlasiy, I. P. (2015). Pedagogika [The pedagogy]. Moscow: VLADOS.

Rudneva, T. I., Astakhova S. V., Lapshova E. S. (2007). Professional'naya podhotovka spetsialistov humanitarnoho profilia [Professional training of specialists of humanitarian profile: monograph]. Samara: Samara University.

Slastenin, V. A., Isayev I. F., Shiyanov Ye. N. (2015). Pedagogika: ucheb. posobiye dlya stud. vyssh. ped. ucheb. zavedeniy [The pedagogy: textbook]. Moscow: School Press. 
Tkachova, T. M. (2015). Rol' lichnosti v obespechenii kachestva prfessional'noy podgotovki vypusknikov vuza: uchebnoye posobiye [The role of the individual in ensuring the quality of vocational training of graduates of the university]. Moscow: MADI. 2015.

Vasil'iev, A. D. (2015). Slovo v rossijskom teleefire [The word on Russian television]. Moscow: Science, pp. 11-155.

Vereshchagin, E. M., Kostomarov V. G. (1976). Yazyk i kultura. Lingvostranovedenie [Language and culture. Linguistic studies]. Moscow, p. 356.

Volkogonova, O. D., Chaplygin A. K. (2005). Orientirujas' na Bolonskij protsess: opyt transformatsii vysshego obrazovaniya $v$ Rossii i Ukraine [Focusing on the Bologna process: the experience of the transformation of higher education in Russia and Ukraine] in Modern technologies of training specialists in conditions of further development of higher education in Ukraine. Kharkov, pp. 192-194.

Zimnyaya, I. A. (2010). Pedagogicheskaya psikhologiya : uchebnik dlya vuzov [Pedagogical psychology: the textbook]. $3^{\text {rd }}$ ed. Moscow: Moscow Institute of Psychology and Sociology; Voronezh: MODEK.

For citation:

Bielikova, O. \& Dytiuk, S. (2019) MONITORING PROFESSIONAL COMPETENCE OF A LECTURER IN FOREIGN CITIZENS` LANGUAGE TRAINING. International Scientific-Pedagogical Organization of Philologists “ WEST-EAST” (ISPOP). Scientific Journal WEST-EAST. Vol 1/1 N1 (October, 2019). pp. 136-139. doi:

Для цитирования:

БеЛикова, Е., ДЫтюк, С. (2019) МОНИТОРИНГ ПРОФЕССИОНАЛЬНОЙ КОМПЕТЕНЦИИ ПРЕПОДАВАТЕЛЯ

ЯЗЫКОВОЙ ПОДГОТОВКИ ИНОСТРАННЫХ ГРАЖДАН // International Scientific-Pedagogical Organization of Philologists “ WEST-EAST ”(ISPOP). Scientific Journal WEST-EAST. Vol 1/1 N1 (October, 2019). C. 136-139. doi:

Information about the authors: Olena Bielikova - Senior Lecturer, Kharkiv national university of civil engineering and architecture, Kharkiv, Ukraine

e-mail:khnuba.ukrmova@gmail.com

belikova.lenochka@gmail.com

Svitlana Dytiuk - Senior Lecturer, Kharkiv national university of civil engineering and architecture, Kharkiv, Ukraine

e-mail: khnuba.ukrmova@gmail.com

Svetlanadytiuk@gmail.com

Сведения об авторах: Елена Беликова - старший преподаватель, Харьковский национальный университет строительства и архитектуры, Харьков, Украина

e-mail: khnuba.ukrmova@gmail.com

belikova.lenochka@gmail.com

Светлана Дытюк - старший преподаватель, Харьковский национальный университет строительства и архитектуры,

Харьков, Украина

e-mail: khnuba.ukrmova@gmail.com

Svetlanadytiuk@gmail.com

DOI:

\title{
CULTURE CONTACT AND VALUES CONFLICT IN TEACHING RUSSIAN AS A FOREIGN LANGUAGE
}

\author{
Liudmila Bogdanova \\ Doctor of Philology, Professor \\ Lomonosov Moscow State University \\ (Moscow, Russia) \\ e-mail: libogdanova1@mail.ru
}

\begin{abstract}
The article discusses the interaction of cultural values in teaching Russian. The purpose of the article is to show the universal and national-specific in the cultural spaces of languages that come into contact in learning of Russian as a foreign language. During the research various methods and operational procedures were used including analysis of definitions, component analysis, context transformation, equivalent replacement, modeling, linguistic experiment, etc. In the article the ways of reflection of cultural values in language are considered. The special attention is paid to the research of values conflict in the conditions of culture contact. The estimated sign of evaluation can be changed depending on the point of view that the value fixes: the view from the inside or the view from the outside. The structure of views about the same event can not correspond in different cultural communities. This work is deeply connected with such topical questions as formation of associative potential of words, national and cultural specificity of connotations, the means of its lexicographical representation, decoding of speaker's value system.
\end{abstract}

Key words: cultural values, evaluation, values conflict, culture contact, Russian as a foreign language 